\title{
Titration of Trachoma Virus with Observations on Yolk-sac Infection and Sensitivity to Oxytetracycline, using the Single-dilution method
}

\author{
By J. F. WATKINS \\ Sir William Dunn School of Pathology, University of Oxford
}

(Received 17 March 1961)

\begin{abstract}
SUMMARY
The T'ang strain of trachoma virus was titrated in chick embryo yolk sac by a single-dilution method (Golub, 1948), using 3-6 eggs/dilution. The limitations incurred by the use of small numbers of eggs are discussed. The method was used to make observations on the fate of virus after inoculation into the yolk sac, and to study the sensitivity of virus to oxytetracycline. The method was found to be unsuitable for titration of neutralizing antibodies in fowl serum.
\end{abstract}

\section{INTRODUCTION}

The experiments described in this paper were carried out for two reasons. Firstly to examine the efficacy of Golub's (1948) single-dilution method of titration when applied to the T'ang strain (T'ang, Chang, Huang \& Wang, 1957) of trachoma'virus, using smaller numbers of fertile eggs than Golub employed for psittacosis virus; secondly, to use this titration method to make some observations on the behaviour of the virus in the chick embryo and yolk sac.

\section{METHODS}

Virus. The T'ang strain of virus was used throughout. It was received as twentysixth yolk-sac passage material from Dr L. H. Collier (M.R.C. Trachoma Research Unit, Lister Institute, London). Virus stocks were prepared by homogenization of infected yolk sacs made up to a total volume of $10 \mathrm{ml}$. with sucrose + potassium glutamate (SPG) solution (Bovarnick, Miller \& Snyder, 1950). The crude homogenate was distributed in 0.5 or $1.0 \mathrm{ml}$. amounts in ampoules, rapidly frozen, and stored at $-70^{\circ}$. Fresh stocks were made about every 2 months.

Inoculation of yolk sacs. Except when stated otherwise, virus was injected in $0.2 \mathrm{ml}$. quantities into the yolk sacs of eggs after 7 days' incubation at $37^{\circ}$. The eggs were then incubated at $35^{\circ}$ and candled daily. Embryos dying within 3 days of inoculation were discarded. After the first deaths had occurred eggs were candled twice daily. Smears were made of yolk sacs of all dead embryos and stained with $1 / 5(\mathrm{v} / \mathrm{v}$ ) Giemsa stain (G. T. Gurr, London) in pH 6.8 buffer for $30 \mathrm{~min}$. From more than a hundred such smears made in the early stages all but a few contained elementary bodies; therefore embryos found dead with negative smears were not included in the results. All dilutions of virus were made in sucrose + potassium glutamate solution. 
Oxytetracycline. Soluble tablets of oxytetracycline hydrochloride (Pfizer) were use to prepare fresh solutions within $1 \mathrm{hr}$. of injection into eggs. The tablets were dissolved in phosphate buffered saline (pH 7·2). Sensitivity determinations were made by inoculating into 7 -day yolk sacs $\mathbf{0 . 2} \mathrm{ml}$. of a mixture of stock virus and oxytetracycline solution in which the final concentration of virus was $1 / 10$ and the amount of oxytetracycline was as shown (Tables 5 and 7 ).

Antiserum. Antiserum was prepared by injecting $0.5 \mathrm{ml}$. of stock virus intraperitoneally into a hen at weekly intervals for 5 weeks. Blood was collected by heart puncture before the first injection and 1 week after the last injection. The second serum gave a titre of $1 / 128$ in an indirect complement-fixation test against a suspension of virus partly purified by extraction with ether followed by differential centrifugation.

Neutralization test. Virus and fowl antiserum were mixed to give the final dilutions shown in Table 8. After incubation at $35^{\circ}$ for $15 \mathrm{~min} .0 \cdot 2 \mathrm{ml}$. of each mixture was inoculated into three 7 -day-old eggs which were incubated at $35^{\circ}$ and candled daily thereafter.

\section{RESULTS}

\section{Assessment of the single-dilution method of titration}

Golub (1948) described a single-dilution method of titrating the infectivity of psittacosis virus, using 10-30 fertile eggs per dilution, and estimating the mean survival time after inoculation of virus. It was found possible to titrate the T'ang strain by this method, with fewer eggs than Golub used, and a consequently diminished accuracy. For some purposes, however, 3-4 eggs per point enable limited conclusions to be drawn from the mean survival times. The regression of survival times on $\log _{10}$ LD50 inoculated was examined by inoculating 4-6 eggs with tenfold dilutions of stock virus. Eggs were incubated for a further 14 days, and the LD50 calculated by Thomson's Method of Moving Averages (Thomson, 1947). Embryos surviving for the whole 14 days were considered to be uninfected. The mean values of the survival times, even for such small groups of eggs, lay fairly close to a straight line drawn by eye (Fig. 1), which supported the idea that the relationship of survival time to infectivity of the inoculum was the same as that described by Golub for psittacosis virus.

An estimate of the number of elementary bodies in one LD50 was made by spreading $0.02 \mathrm{ml}$. of stock virus evenly over a ruled area of $4 \mathrm{~cm}^{2}$ on a slide, staining with Giemsa, and counting the number of bodies in five microscope fields at a magnification of 1700 . Two values for the LD50 obtained in this way were 7600 and 554 elementary bodies. Several similar counts were performed during these experiments on yolk sac homogenates prepared from embryos dying between the fifth and tenth days after infection. These gave values of $10^{\circ}$ to $10^{10}$ elementary bodies per yolk sac at death. The multiplication, in terms of elementary bodies, of an inoculum which killed embryos 14 days after infection was therefore of the order of $10^{6}$ to $10^{7}$ times.

An assessment of the sensitivity of the method is given in Table 1, taking the regression of survival time on dilution of virus inoculated as linear. A difference in infectivities equivalent to a dilution of less than about one in thirty would not be expected to show as a significant difference between mean survival times. 


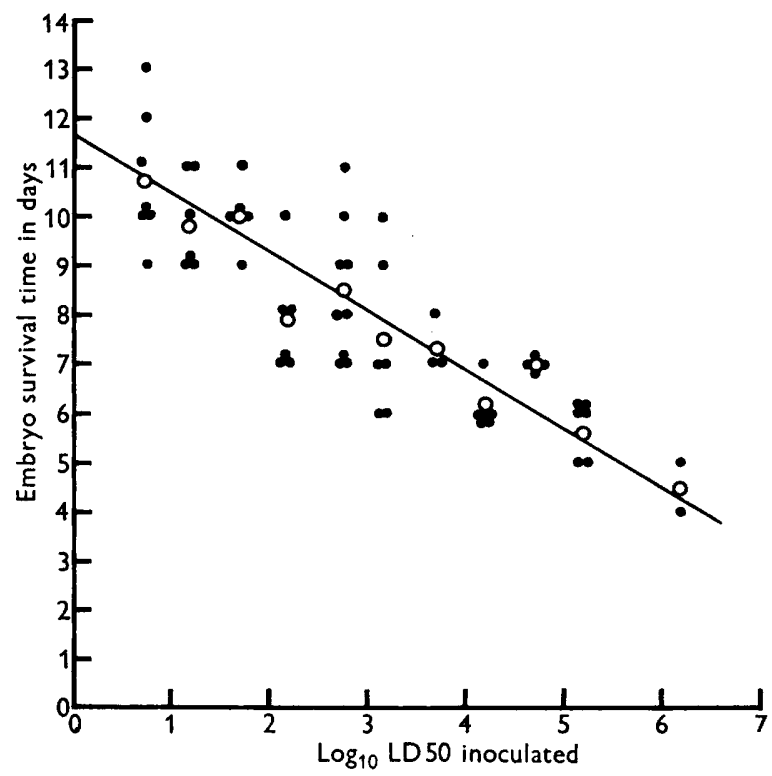

Fig. 1. Regression of survival time of embryos on $\log _{10}$ LD50 of Trachoma virus (T'ang strain) inoculated into the yolk sac. $O$, mean survival times.

This application of the single-dilution method of Golub is therefore extremely coarse, but it is economical and will enable useful conclusions to be drawn provided that the limitations are borne in mind. To avoid the additional sources of variation involved in determining the LD50, the results of titrations are expressed throughout this paper as the mean survival time (MST) of a group of 4-6 embryos after injection

Table 1. Sensitivity of method of titration

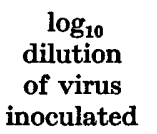

$$
\text { : }
$$$$
1
$$$$
\mathbf{2}
$$$$
\mathbf{3}
$$

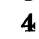$$
\mathbf{5}
$$

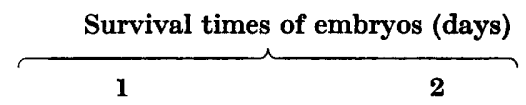

$$
\begin{aligned}
& 4,5 \\
& 5,5,6,6,6 \\
& 6,6,6,6,6,7 \\
& 6,6,7,7,9,10 \\
& 7,7,7,8,8,10 \\
& 9,9,9,10,11,11
\end{aligned}
$$

If Mean Survival Time (MST) $=K \times \log _{10}$ dilution of inoculum, 1 day $=$ about $1 \log _{10}$ unit (Fig. 1). Variance of single observation = about 1 day. Variance of MST of 4 embryos $=$ about 1 day. Variance of difference between MST values in groups of 4 embryos $=\frac{1}{2}$ day, and s.D. $=1 / \sqrt{ } 2$ day. Therefore difference will be significant at $95 \%$ level if it exceeds $2 \times$ s.D. $=$ about $\sqrt{ } 2=$ about $1 \cdot 4$ days.

on the seventh day of incubation of $0.2 \mathrm{ml}$. of virus suspension. The abbreviations in brackets after the abbreviation MST indicates the source of the material inoculated, for example, MST(YS), means that the figure given is the mean survival time of a group of eggs after the injection of yolk-sac suspension; in the text this may be expressed as the MST of a suspension. Embryos surviving the whole 
14-day period are treated for quantitative purposes as though they died on the fourteenth, so that an MST of 14 days implies that all the embryos survived. This is necessary to deal with such a result as the death of one embryo in a group before 14 days, and the survival of the others.

\section{Observations on growth of the virus}

\section{Effect of infection on embryo and yolk-sac development}

A possible explanation for the relationship between survival time and inoculum is that the growth rate is independent of the size of the inoculum and that the embryo will die when a certain number of cells has been irreparably damaged. There could also be a slow toxic action of the material inoculated. The increase in weight of small numbers of infected embryos was not greatly different from that of uninfected embryos (Table 2). This is not the kind of result to be expected of some toxic effect beginning soon after inoculation.

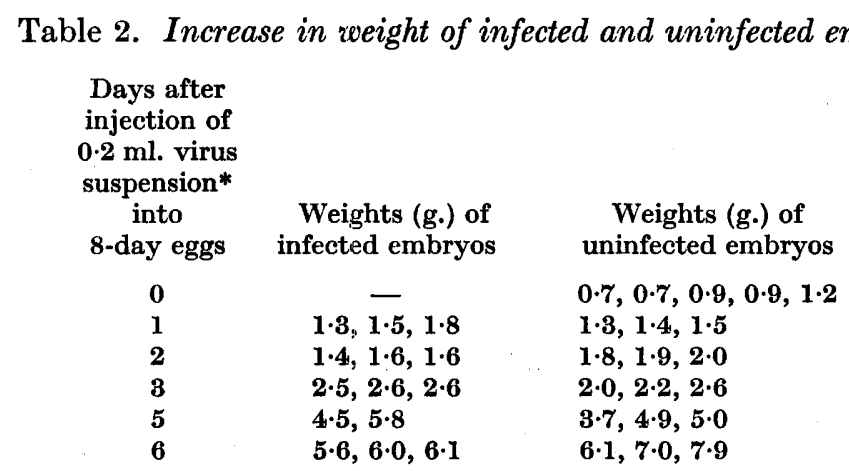

* Stock virus diluted 1/10. Survival time 6-7 days.

In another experiment yolk sacs harvested at intervals after infection increased in weight in the same way as uninfected yolk sacs until a day or two before death of the embryo, at which time they actually fell in weight (Fig. 2).

\section{Distribution of virus after inoculation of yolk sac}

The infectivity of yolk after inoculation with virus was determined by removing the shell over the air-space and aspirating a quantity of yolk from the yolk sac which was easily visible beneath the shell membrane. The aspired yolk was used to inoculate other eggs in $\mathbf{0 . 2} \mathrm{ml}$. amounts, without further dilution (Table 3). Suspensions for the titration of yolk-sac infectivity were prepared by washing the sac carefully in two changes of phosphate buffered saline and homogenizing it in a total volume of $10 \mathrm{ml}$. of sucrose + potassium glutamate solution. When the homogenate was not to be inoculated into eggs at once it was rapidly frozen and stored at $-70^{\circ}$ until required. Storage of virus in this way caused some loss of infectivity (Table 3 ). $0.2 \mathrm{ml}$. of homogenate was inoculated into the eggs used for titration. In one experiment embryos were titrated for infectivity in the same way as yolk sacs (Table 3). When the volume of yolk is taken as $20 \mathrm{ml}$., the dilution of the inoculum after injection is $1 / 100$, so that the infectivity of yolk immediately after inoculation 


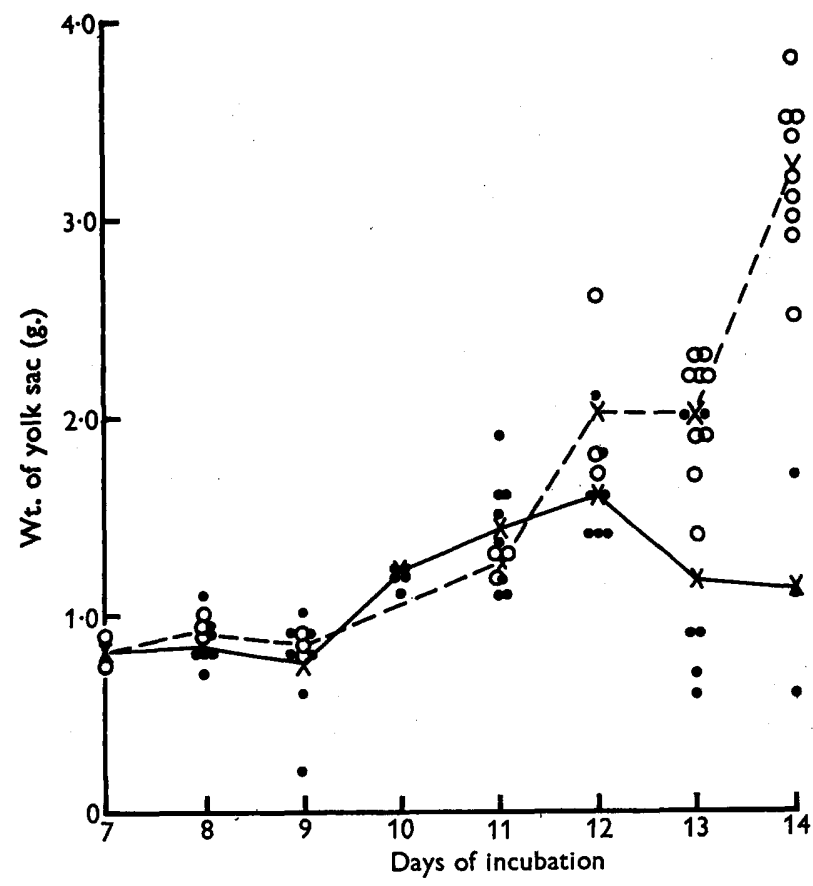

Fig. 2. Growth of normal yolk sacs and yolk sacs infected on the seventh day of incubation.

$O$, Normal yolk sacs; 0 , infected yolk sacs; $x$, mean weights.

would be expected to show an MST 2-3 days greater than the inoculum and this expectation is borne out by the figures (Table 3). One day after injection infectivity could still be recovered from the yolk in quantities similar to that present immedi-

Table 3. Infectivity of yolk, yolk sacs, and embryos at intervals after inoculation of virus

\begin{tabular}{|c|c|c|c|c|c|c|c|c|c|}
\hline \multirow{2}{*}{$\begin{array}{l}\text { Expt. } \\
\text { no. }\end{array}$} & \multirow{2}{*}{$\begin{array}{l}\text { MST of } \\
\text { inoculum }\end{array}$} & \multirow{2}{*}{$\begin{array}{c}\text { Infectivity } \\
\text { of }\end{array}$} & \multicolumn{7}{|c|}{ Days of incubation at $35^{\circ}$ after inoculation } \\
\hline & & & 0 & 1 & 2 & 3 & 4 & $\mathbf{5}$ & 6 \\
\hline $\mathbf{2 8 b}$ & $6 \cdot 4$ & Yolk* & - & 14 & - & 一 & - & - & 一 \\
\hline & & Yolk sac* & - & 14 & $9 \cdot 0$ & $\mathbf{7 \cdot 0}$ & $7 \cdot 0$ & $5 \cdot 0$ & $5 \cdot 0$ \\
\hline - & & Embryos* & - & 14 & 14 & $11 \cdot 0$ & - & $6 \cdot 3$ & $8 \cdot 0$ \\
\hline 56 & $5 \cdot 4$ & Yolk sac* & - & $13 \cdot 5$ & $7 \cdot 5$ & 一 & $6 \cdot 0$ & 6.8 & - \\
\hline $82 a$ & $6 \cdot 0$ & Yolk & $8 \cdot 0$ & $7 \cdot 0$ & - & - & - & - & - \\
\hline & & Yolk sac & - & $9 \cdot 5$ & - & 一 & - & - & - \\
\hline $82 b$ & $6 \cdot 0$ & Yolk & $7 \cdot 0$ & $7 \cdot 0$ & - & - & - & - & - \\
\hline & & Yolk sac & - & $11 \cdot 0$ & - & - & 一 & 一 & - \\
\hline 78 & $9 \cdot 0$ & Yolk & $11 \cdot 0$ & $10 \cdot 0$ & - & 一 & 一 & - & - \\
\hline & & Yolk sac & - & 10.0 & - & - & - & - & 一 \\
\hline
\end{tabular}

ately after injection. Infective virus could also be recovered from washed homogenized yolk sacs 1 day after inoculation. The presence of significant amounts of infective virus in the yolk even 1 day after inoculation implies that absorption of virus by entodermal cells may continue for too long after injection to make this system a useful one for studies on the kinetics of virus growth. 


\section{Phagocytosis of Indian ink by yolk sac}

In order to test the possibility of dispersal of virus throughout the whole egg contents after inoculation a $10 \%(\mathrm{v} / \mathrm{v})$ suspension of 'Pelikan' ink was injected into the yolk sacs of several 7 -day-old eggs which were incubated at $35^{\circ}$. The contents of these eggs were examined at intervals after injection. Fifteen minutes after injection washed yolk sacs showed a faint grey band (Pl. 1, fig. 1). Over the next $24 \mathrm{hr}$. this band increased in density and slightly in width, and at this time ink was present only in the yolk-sac contents. Histological sections showed widespread uptake of ink by entodermal cells with a heavy concentration in the position of the band. There may therefore not be much dissemination of inoculatedivirus throughout the egg, and phagocytosis may play at least some part in the entry of virus into cells.

\section{Effect of oxytetracycline on infection}

The embryos were protected by $20 \mu \mathrm{g}$. of oxytetracycline against all the doses of virus used. Below this amount of oxytetracycline the sensitivity was inversely related to the dose of virus (Table 4). For example, $5 \mu \mathrm{g}$. oxytetracycline failed to

Table 4. Effect of size of inoculum of virus on sensitivity to oxytetracycline $(O T)$

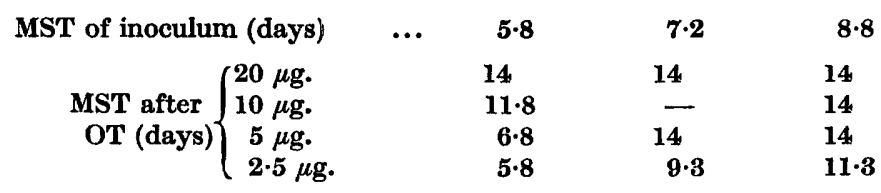

protect against an inoculum whose MST was 5.8 days, whereas the same dose protected against an inoculum whose MST was $7 \cdot 2$ days.

The phenomenon of delayed death shown in the first column of Table 4 was observed several times in this system, and a similar effect was reported for this and other antibiotics acting on the psittacosis-lymphogranuloma group by Katz (1956) and Jawetz \& Hanna (1960 b). It must be due to one of three causes, decay of antibiotic, retardation of virus growth, or appearance of a resistant variant. The third possibility was examined by testing the sensitivity of the virus recovered from the yolk sacs in the eggs which showed a delayed death after $10 \mu \mathrm{g}$. oxytetracycline. No increase of resistance was detected.

Table 5. Effect of time of addition of oxytetracycline (OT) on its ability to protect infected embryos

\begin{tabular}{crrccccc}
$\begin{array}{c}\text { Days after infection on } \\
\text { which 50 } \mu \text { g. OT added }\end{array}$ & 0 & 1 & 2 & 3 & 4 & 5 & $\begin{array}{c}\text { No OT } \\
\text { MST }\end{array}$ \\
\hline & 14 & 1.4 & 14 & $13 \cdot 4$ & 10.0 & 8.2 & 6.5
\end{tabular}

It was interesting to know at what time after inoculation death could no longer be prevented by antibiotic treatment. This method was used very successfully by Keppie, Smith \& Harris-Smith (1955) in studying infection of guinea-pigs with Bacillus anthracis. After inoculation of virus, groups of 4-6 eggs were injected at 
$24 \mathrm{hr}$. intervals with $0.2 \mathrm{ml}$. oxytetracycline solution containing $50 \mu \mathrm{g}$. antibiotic. Embryos were completely protected up to 2 days after infection, almost completely after 3 days, and with decreasing efficiency after 4 and 5 days (Table 5). Several determinations were made of the amount of infectivity that could be recovered from yolk sacs some days after the administration of a protective dose of oxytetracycline (Table 6). Infective virus could be recovered from the yolk sac 14 days after injection when oxytetracycline was injected more than 2 days after virus injection.

Table 6. Survival of virus in yolk sac after oxytetracycline (OT)

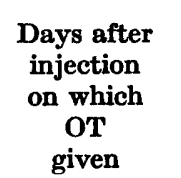

0

1

2

3

$\mathbf{3}$

3

$\mathbf{8}$

$\mathbf{4}$

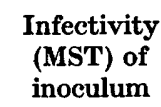

$\mathbf{7 \cdot 0}$

$6 \cdot 5$

$6 \cdot 5$

$6 \cdot 5$

$7 \cdot 9$

$7 \cdot 9$

$6 \cdot 0$

$6 \cdot 5$

$6 \cdot 5$
Infectivity (MST) of infected yolk sacs at these intervals (days) after inoculation of virus

$\begin{array}{cccccccc}\begin{array}{c}\mu \text { g. OT } \\ \text { injected }\end{array} & 2 & 3 & 4 & 6 & 8 & 10 & 14 \\ 100 & 14 & - & - & - & - & - & 14 \\ 100 & - & - & - & - & 14 & - & - \\ 100 & - & - & - & - & 14 & - & 14 \\ 100 & - & - & - & - & 7 \cdot 7 & - & 8 \cdot 5 \\ 50 & - & 11 \cdot 8 & - & - & - & - & 14 \\ 50 & - & 12 \cdot 0 & - & - & - & - & 14 \\ 50 & - & (7)^{*} & - & 10 \cdot 0 & 9 \cdot 0 & 9 \cdot 3 & (8)^{*} \\ 100 & - & - & - & - & 7 \cdot 5 & - & - \\ 100 & - & - & - & - & 5.0 & - & 9 \cdot 0\end{array}$

* Survival time of one embryo.

Table 7. In vitro effect of oxytetracycline $(O T)$

Virus $0.5 \mathrm{ml}$. +yolk $10 \mathrm{ml}$. + OT $1 \mathrm{mg}$. at $35^{\circ} / 24 \mathrm{hr} .0 .2 \mathrm{ml}$. of $1: 10$ dilution (containing $2 \mu \mathrm{g}$. OT + stock virus $1 / 200$ ) injected into yolk sac.

$\begin{array}{cc}\begin{array}{c}\text { Duration of } \\ \text { exposure of } \\ \text { virus to OT }\end{array} & \begin{array}{c}\text { MST of virus/OT } \\ \text { mixture } \\ \text { (days) }\end{array} \\ \text { 0 min. } & 10.0 \\ 24 \mathrm{hr} . & 10.6\end{array}$

There was some decrease in the degree of infectivity which could be due to thermal inactivation, metabolic activity of the cells, or mechanical removal of virus. A slow viricidal effect of oxytetracycline cannot strictly be excluded, but this is made unlikely by the absence of a viricidal effect in $24 \mathrm{hr}$. incubation of virus in the presence of $100 \mu \mathrm{g}$. oxytetracycline/ml. (Table 7), a concentration many times greater than that to which intracellular virus would have been exposed. These experiments provided no evidence against the idea that oxytetracycline exerts a virustatic effect on this strain of trachoma virus.

Table 8. Neutralization of T'ang virus (MST's of serum/virus mixtures)

\begin{tabular}{|c|c|c|c|c|}
\hline \multirow{3}{*}{$\begin{array}{c}\text { Final } \\
\text { virus } \\
\text { dilution }\end{array}$} & \multicolumn{4}{|c|}{ Figures in parentheses $=\%$ 'neutralization'. } \\
\hline & \multicolumn{3}{|c|}{ Final antiserum dilution } & \multirow{2}{*}{$\begin{array}{c}\text { Normal } \\
\text { serum } \\
1 / 2\end{array}$} \\
\hline & $1 / 2$ & $\mathbf{1} / \mathbf{1 0}$ & $1 / 100$ & \\
\hline $10^{-1}$ & $8 \cdot 0(99 \cdot 3)$ & $5 \cdot 5$ & $5 \cdot 5$ & $5 \cdot 5$ \\
\hline $10^{-2}$ & $9 \cdot 0(99 \cdot 7)$ & $7 \cdot 0$ & $5 \cdot 6$ & $6 \cdot 0$ \\
\hline $10^{-3}$ & $10 \cdot 0(97 \cdot 8)$ & $\mathbf{8 \cdot 3}$ & $8 \cdot 0$ & $8 \cdot 0$ \\
\hline
\end{tabular}




\section{Neutralization of virus}

Fowl antiserum diluted $1 / 2$ produced a prolongation of mean survival time of 2-3 days with all three dilutions of virus. There was no prolongation with the higher dilutions of serum (Table 8).

\section{DISCUSSION}

Dependence of survival time upon the amount of trachoma virus inoculated into yolk sacs was shown by Jawetz \& Hanna (1960a) who used three strains isolated in the United States. They found that $10^{5} \mathrm{LD} 50$ doses killed embryos in 5-6 days, and 10 LD 50 killed in 10-12 days, which agrees with the survival times recorded here for the T'ang strain. Since appreciable amounts of infectious virus were found in embryos 3 days after infection (Table 3 ), and embryos could survive for 2 weeks after inoculation of virus when they were protected by the virustatic action of oxytetracycline injected 3 days after infection (Table 6), it is unlikely that the virus kills embryos by a toxic action of the kind described in mice by Bell, Snyder \& Murray (1959). The loss of weight of infected yolk sacs (Fig. 2) may have been due to the fact that a high proportion of the weight of the yolk sac consists of materials in transit from yolk to embryo (Romanoff, 1960); it may be that when infection has damaged cells beyond a certain point they are no longer able to take up yolk material, but can still pass on, or metabolize, what they already contain. On this hypothesis lack of nutrients contributes to the death of the embryo. Such fatal damage to the entodermal cells must occur a short time before the death of the embryo, since infected embryos weighed the same as uninfected ones, and the growth curve of infected yolk sac followed that of uninfected until a day or two before death (Fig. 2).

Katz (1956) found that feline pneumonitis virus was inhibited by $31 \mu \mathrm{g}$. tetracycline or oxytetracycline. Jawetz \& Hanna (1960b) found that two of their strains were inhibited by $2 \mu \mathrm{g}$. tetracycline $/ \mathrm{ml}$. (that is, $\mathbf{1} \cdot 0 \mu \mathrm{g}$. in the inoculum). The T'ang strain was inhibited completely by $20 \mu \mathrm{g}$. oxytetracycline.

A possible explanation of the inverse relationship of sensitivity to virus dose below $20 \mu \mathrm{g}$. oxytetracycline (Table 4) may be that an intracellular threshold concentration of oxytetracycline is attained after injection of less than $20 \mu \mathrm{g}$. which can inhibit the development of one infective particle/cell, such as may occur after a small inoculum, but not of two or more, which would be present in many cells after a large inoculum. Katz (1956) found that the activity of tetracycline on feline pneumonitis virus was independent of the inoculum. His figures suggest that feline pneumonitis virus is more lethal for chick embryos than trachoma virus. For example $10^{4} \mathrm{LD} 50$ doses of feline pneumonitis virus gave a mean survival time of $5 \cdot 2$ days, whereas the same dose of trachoma virus killed in $7 \cdot 0$ days. It is therefore possible that at a dosage level of $10^{5} \mathrm{LD} 50$ doses of feline pneumonitis virus most infected cells contained one particle only. If the hypothesis is correct that an intracellular threshold amount of antibiotic is required to inhibit one intracellular particle, the difference between the findings of Katz and those in Table 4 can be explained.

The failure of a fowl antiserum to neutralize the T'ang strain completely is disappointing. Even the slight prolongation of survival time may have been due, for example, to agglutination rather than neutralization. The system itself is not very 


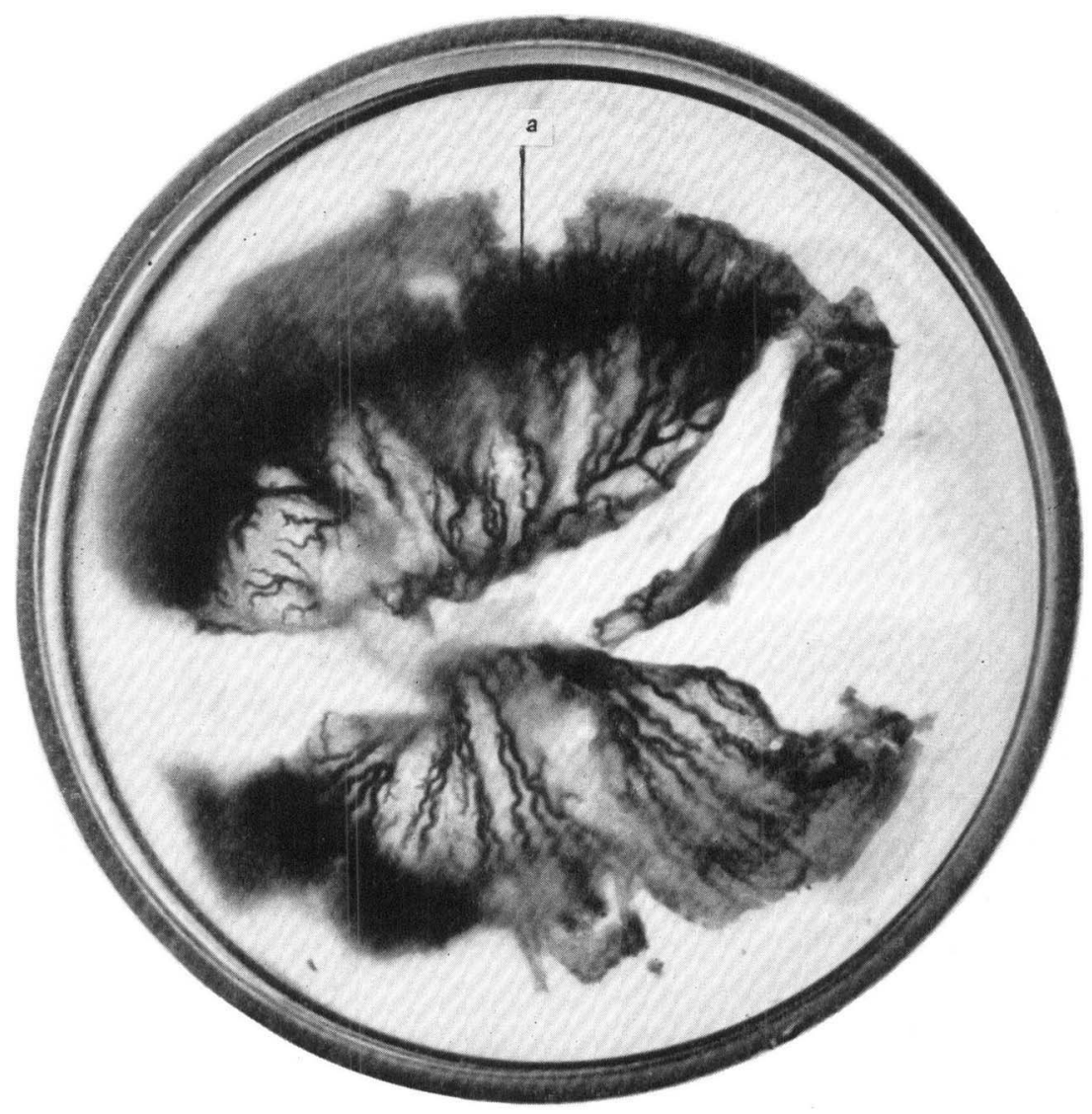

